\title{
A case for tolerance in marine ecology: let us not put out the baby with the bathwater*
}

\author{
WOLF E. ARNTZ ${ }^{1}$ and JOSEP-MARIA GILI ${ }^{2}$ \\ ${ }^{1}$ Alfred Wegener Institute for Polar and Marine Research, 27658 Bremerhaven, Germany. \\ ${ }_{2}^{2}$ Institut de Ciències del Mar (CMIMA-CSIC), Passeig Marítim de la Barceloneta 37-49, 08003 Barcelona, Spain.
}

\begin{abstract}
SUMMARY: After working in marine ecological research and lecturing at universities for several decades, the authors are aware that almost none of the concepts and paradigms established at the time they were students or in the decades before have survived unchanged up to the present day. This appears quite natural taking into account the enormous progress made by marine science due to refined methods, extended range of research e.g. into the deep sea and the polar regions, increased number of researchers and funding, and greatly improved and accelerated exchange of scientific results. What is striking, however, against this background is the almost messianic fervour with which many of our professional guild (and not only the younger ones lacking experience) call for the immediate "abolishment" or "dismissal" of old ideas because their creators were wrong in thinking the way they did. In these authors`opinion, there is a basic misunderstandig about the role of ecological concepts in scientific argumentation. Very few concepts are so foolish that they can be dismissed entirely without any loss; the vast majority contain some truth that may fit at least certain situations, and may thus serve as a brickstone in constructing ecological theory. An attempt will be made to expand on that point in this contribution. What is more important: many of the concepts nowadays considered (partially?) erroneous have stimulated scientific discussion enormously, in some cases up to the present day and have, by their mere existence, guaranteed that ecological work was found necessary to continue in the respective fields. Finally, observing the tremendous pace at which ecological progress is being made these days in some disciplines and at the same time, the degree of uncertainty we are - despite all efforts - still facing in others, it is not difficult to anticipate that many of the new ideas replacing the old concepts nowadays will end up shortly on the garbage dump of science history as well. So tolerance should be the motto: let us not put out the baby with the bathwater! Give the old concepts their credit, look eagerly for alternatives and try to provide the best possible evidence for your results, but be modest. There may be various solutions to one ecological problem, and the way to handle this situation is differentiation, not abolishment.
\end{abstract}

Key words: stimulating scientific discussion, new ideas replacing old concepts, science history, tolerance, Thorson's rule, polar regions.

\section{THE PROBLEM}

"Whenever a theory appears to you as the only possible one, take this as a sign that you have neither understood the theory nor the problem which it was intended to solve"

Karl Popper, 1972

\footnotetext{
*Received August 10, 2001. Accepted August 17, 2001.
}

"Theories are, sorry to say, often mistaken for something only theoretical, i.e. not resting on facts. Theories are, however, in reality the only framework within which facts, of any kind, begin to make sense" Rupert Riedl, 1980

During our scientific carreer, we have often encountered a tendency, above all in thesis work, to propose new findings in a way that they finished (once for ever!) with former concepts on the subject 
which, therefore, had to be "dismissed" or "abolished". While this may be explained by lack of experience, it strikes us to find this attitude also with colleagues of solid scientific standing who should be well acquainted with the ephemeral nature of presumed truth in the natural sciences.

As we would like not to be misunderstood from the beginning: We are (of course) not at all in favour of an uncritical acceptance of scientific paradigms, or against a discussion of obvious controversies, or against ecological progress based on new facts and findings! But most new theories and hypotheses are based at first on a limited amount of information and a lot of intuition. Only the increase of information in the process of verifying these ideas enables us to confirm or to reject them, and has in many cases resulted in their actualisation, extension and diversification. One of the approaches which have added substantially to our knowledge, and where the person we are celebrating with this meeting has made a very important contribution, is multidisciplinary research combining different branches of science such as biology and physics. Besides, Ramón Margalef is a living example of how very different approaches and opinions can be integrated to construct a theoretical superstructure, notwithstanding the fact that he has always been one of those scientists who have contributed very original ideas of their own. In fact, some of the ideas put forward in his most recent books (Margalef, 1991, 1997) are so far in advance of the thoughts of most ecologists that just recognition may be delayed for some time.

Margalef is a good example that the creators of ecological concepts, often involving a high degree of intuition, are usually ahead of their colleagues on the applied science level, who test (and often disprove) the concepts. We claim, however, that certain elements of theories remain valid despite the fact that subsequent thinking may lead into a different direction or may use a different vocabulary: see, e.g. the differential use of "stability" in more recent literature (Grimm and Wissel, 1997); or the greatly changed use of diversity indices and the recent introduction of the new term "biodiversity" (Wilson, 1988; Margalef, 1997). Should we -in the possession of much improved information-blame the old ecologists for their attempts to develop conceptual bases with the scant facts they had at hand in their time? Did the Lotka-Volterra models (Volterra, 1928) not make a stimulating contribution to ecological discussions on predator-prey relations, despite the fact (as Margalef used to say) that their agreement with nature was rather coincidental?
IN THE PAST MANY QUESTIONS APPEARED SOLVED...

When the first author was a young benthic ecologist in Kiel, trying to pick up the ideas that had been sown by the great Baltic benthic researchers of the past -Möbius, Petersen, Blegvad, Boysen-Jensen, Remane, Lindroth, Segerstrale, Thorson- and to keep pace with what the Askö research group around Bengt-Owe Jansson and the oxygen deficiency workers around Rutger Rosenberg were doing in Sweden, an exciting time had started for benthic ecology. Still being something exotic at the turn of the century, a branch that mainly served practical purposes of the fisheries biologists interested in "boniteringer" of fish food, it had developed a scientific character of its own, spread all over Europe and gained a strong position in North America. We were almost flooded with exciting concepts: Remane had inspired a whole school of successors to look into the recently detected world of mesopsammon, the interstitial fauna of sandy bottoms, Thorson had discovered parallel communities around the world and offered a concept of invertebrate reproductive strategies which was to be known as Thorson's rule, the bell-shaped distribution of benthic fauna along the latitudinal gradient was greatly accepted. Sanders had become famous for his community research and a worldwide concept to explain poor, "predominantly physically adapted" and diverse, "biologically accommodated" communities based on a stability time hypothesis, which was rapidly challenged by Dayton and Hessler's concept of disturbance creating and maintaining diversity. Connell and Huston came up with the intermediate disturbance hypothesis, Paine provided insights into species interactions in the rocky intertidal. Exciting news were gradually arriving from the Antarctic, until then better known for its seal slaughterers and whale hunters than for its remarkable bottom fauna, because of the establishment of research stations and the use of ice breaking research vessels, and scientists started dreaming about the unlimited possibilities of huge amounts of krill produced in excess to feed a starving humanity. At the same time, a paradigm developed of benthic organisms living under almost constant environmental conditions in the Southern Ocean scratching, however, a miserable life as seemingly they had to subsist entirely on the short seasonal peaks of phytoplankton availability...

The second author, working in the Mediterranean, experienced a very basic and detailed taxo- 
nomic training when he arrived at the Barcelona Ecological Department, due to Margalef's conviction that any ecological work must be based on a sound taxonomic background (a fact that is forgotten by many science managers nowadays, see Dayton, 1990). Guided by Jean Bouillon and thus concentrating on cnidarians, he dived profoundly into the old taxonomists` graphs and texts the superb quality of which can probably never be equalled by modern work. This brought him into connection with the great schools of taxonomists around the Mediterranean which are now becoming extinct: Marseille with specialists like Vacelet, Harmelin and Zibrowius; Genova led by Sara, Tortonese... From these schools a descriptive marine ecology originated, derived from the techniques of terrestrial phytosociologists such as Braun-Blanquet, which influenced marine ecology for decades despite its somewhat subjective character. Keystone publications at the time were papers by the French authors Pérez, Piccard and Laubier, followed by the Austrian school working from Naples and culminating in Riedl's famous work Biologie der Meereshöhlen, which marked the approximation between the merely biological branch of descriptive ecology and its environmental counterpart with the integration of physics. Stimulated by Margalef and giving these aspects a distinct touch towards dynamics and physiology, the Barcelona ecological school then took a lead in the Mediterranean.

We could continue at length with this kind of enumerations to show that by the time we started our work marine ecologists were convinced -just as they are now- that major problems had been solved and could be accepted as a sound basis of knowledge to build further progress upon. E.g., in many cases more recent work in the Mediterranean, of course with other means and a greater rigorosity, rediscovered the excellent findings made by pioneers such as Lo Bianco or Haeckel. Similarly, novel approaches using modern methods for community delimitation (e.g., Garrabou, 1998) would make use of the ecological knowledge assembled during the decades of "descriptive research". However nowadays, with increased possibilities and improved facilities and methods, international cooperation and science exchange, we know that many of the old concepts need, to say the least, a high degree of differentiation. To demonstrate this, we will elaborate on some of these issues, using them as examples of a much wider problem, and limiting ourselves largely to Antarctic cases. This is because Antarctic research has undergone a particularly rapid development in past years -and also, because this research is the principal base of our present cooperation.

\section{OTHER SOLUTIONS SUGGESTED NOWADAYS...}

In the following, we would like to shed some light on a number of paradigms which have been subject to major changes in recent years:

- The Antarctic seafloor is an extremely constant environment almost free of abiotic stress.

- The Antarctic sessile benthos subsists trophically on the strongly seasonal input of phytoplankton blooms and ceases feeding during the remainder of the year.

- Reproduction of Antarctic benthic fauna is predominantly tied to the plankton blooms.

- Meroplanktonic larvae are almost non-existent in Antarctic waters following Thorson's rule.

- Faunal species richness in the Southern Ocean should be low obeying to the bell-shaped curve of species distribution from the tropics to the poles.

In fact, these items are just part of a whole series of paradigms on the Antarctic ecosystem which have been questioned recently, leading to a greatly changed perception of this system. To blame for this development are, apart from the greatly intensified work from land- or ice-based stations and individual efforts of some countries on their research vessels, the great international ship-based research programmes such as BIOMASS, EPOS, EASIZ or SOJGOFS, which have provided a voluminous data base except for winter data which remain scarce for obvious reasons.

\section{"The Antarctic seafloor is an extremely constant environment almost free of abiotic stress"}

Among the old marine environments cited by Sanders $(1968,1969)$ to support his stability time hypothesis were the tropical belt and the deep sea. Not only the long-term existence of these environments on geological time scales, but also their assumed constancy of conditions was supposed to have created a refinement of species interactions resulting in high diversities. While there soon was a contrarious hypothesis to explain high deep-sea diversities rather by disturbance (e.g., predation act- 
ing as a disturbant) than by constancy of conditions (Dayton and Hessler, 1972; Menge and Sutherland, 1977; see also Sanders, 1979), it became evident that there are many different ecosystems in the tropical seas ranging from extremely low to extremely high diversity (e.g., Dexter 1974; Alongi 1990, Crame 2000a,b). Furthermore, recent research led to doubts whether deep-sea diversities are really as high as assumed by some scientists and generally higher than coastal diversities (Gray, 1994; Gray et al., 1997), the detection of the role of aggregates pointed to a higher variability of food availability in the deep sea (Riemann 1989; Wottom, 1994), etc. However, all these findings cannot quite eliminate the fact that large parts of the tropical belt are indeed unusually benign and constant in comparison with other marine environments, and that the patterns of light, temperature, salinity, oxygen, pressure and food availability in the deep sea are more constant over large areas and not simply comparable to most shallow-water ecosystems. So are there possibly (except age, the other variable mentioned by Sanders which seems to be more generally accepted) various factors creating high faunal diversity?

Similarities of deep-sea and Antarctic conditions in the marine realm have been stressed by various authors, e.g. by Lipps and Hickman (1982). When high-diversity marine assemblages were detected in the Ross Sea (Bullivant, 1967; Dearborn, 1968; Dayton and Robilliard, 1971; Dayton et al., 1974), it became almost customary to blame certain constant conditions in the Southern Ocean for this richness. While the light (and thus, the primary production) oscillate stronger than in most other marine ecosystems, temperatures, salinity and oxygen fluctuate much less particularly in the high Antarctic (for a review see Arntz et al., 1994).

However, this presumed constancy of conditions was never valid for the maritime Antarctic with its distinct seasonal fluctuations, the higher input from land, and the eutrophication caused by large bird and seal colonies; nor was it valid for the intertidal and shallow subtidal which are continuously disturbed by the various types of ice (e.g. anchor ice: Dayton et al., 1970). On the Weddell Sea slope and shelf, "warm deep water" can largely increase the normally tiny temperature fluctuations (Arntz et al., 1992), and due to the extreme seasonality of the plankton blooms food availability varies strongly despite the presumed role played by resuspension and advection (Gili et al., 2001).

Recent work has also revealed that iceberg scouring at certain depths of the shelf, mainly between
150 and $300 \mathrm{~m}$, leads to major disturbance in large areas (Gutt et al., 1996; Peck et al., 1999) as it does in the Arctic (Conlan et al., 1998). In agreement with ecological theory, e.g. the intermediate disturbance hypothesis (Connell, 1978; Huston, 1979), the various successional stages co-existing in the iceberg impacted areas enhance diversity at larger scale (Gutt et al., 1998; Gutt, 2000).

So it is disturbance again, not constancy of conditions that creates the diverse epifaunal communities in the high Antarctic, and Sanders' hypothesis of constant conditions creating such diversities has to be dismissed once again?

We are not at all sure. Even in extreme cases, with icebergs capsizing, recent scours do not reach beyond $400 \mathrm{~m}$ depth whereas rich, complex communities on the deep Antarctic shelf and upper slope extend to about twice that depth. So for deeper Antarctic waters, we may not only have to recall Sanders for introducing the factor "time" into the discussion, but there may indeed be an alternate way to high diversity, by what he called stability (meaning constancy) of environmental conditions.

\section{"The Antarctic sessile benthos subsists trophically on the strong seasonal input of phytoplankton blooms and ceases feeding during the remainder of the year"}

On most ocean shelves worldwide, primary production by diatoms and other microalgae contributes strongly to benthic life by fuelling the system (e.g., Margalef, 1974; Graf, 1989; Gili and Coma, 1998), with the extreme in upwelling regions where surface production is often so overwhelming that instead of increasing macrobenthic production, large oxygen minimum zones are created where prokaryotic bacteria are the dominant organisms (Arntz et al., 1991; Fossing et al., 1995). Conversely, high Antarctic sessile epibenthic communities, consisting mainly of sponges, bryozoans, cnidarians and ascidians and building up assemblages of high biomasses, are in obvious contrast to the scarcity of primary production provided by microalgal blooms (Sakshaug, 1994) and the temporal restriction of algal blooms to a few weeks per year (Bathmann et al., 1991). This paradox (Hedgpeth, 1977) led most Antarctic researchers to believe that the suspension feeder communities feast during the bloom period and spend a difficult time of starvation during the rest of the year. There was much discussion as to the functioning of this strategy, which finally was thought to be feasible because the sessile 
fauna did not have to spend much energy in motion, and the great majority appeared to show slow growth and extended longevity.

However, during the EASIZ I cruise a thick layer of fluff was detected in a depression off Kapp Norvegia which did not seem to stimulate any benthic activity (Barthel, 1997). Suspension feeders from the region had almost no microalgae in their stomach contents (Alvà et al., 1997). British researchers at Signy Island (South Orkneys) found that suspension feeders at shallow depths subsist largely on the fine fraction of benthos (Barnes and Clarke, 1995), i.e. on protists, nano- and picoplankton which also oscillate seasonally but to a lower extent, and thus are available year round (Clarke and Leakey, 1996). Consequently, the period of winter lethargy of the suspension feeders was found to be very short, just the reverse of what had been the paradigm (Barnes and Clarke, loc. cit.).

Analysis of stomach contents during the EASIZ cruises in 1998 and 2000, combined with aquarium experiments on suspension feeders on board, revealed a surprising variety of feeding strategies which also included a marked use of the fine fraction of plankton and seston (Orejas et al., in press; subm. a). The hydroid Tubularia ralphii and the anthozoan Anthomastus bathyproctus are zooplanktivorous (Anthomastus can even feed on salps of several $\mathrm{cm}$ length) whereas another hydroid, Oswaldella antarctica, and the gorgonians Primnoisis antarctica and Primnoella sp. are microphagous. The stoloniferan Clavicularia cf. frankliniana presented a mixed diet. These different trophic strategies lead to resource partitioning in the community (Orejas, 2001). This adds to results from former food studies (Gili et al., 1996; Slattery et al., 1997; Cattaneo-Vietti et al., 2000; Cerrano et al., 2000) revealing that these sessile organisms cover the whole range of available food sources in Antarctic waters, each species concentrating on a certain fraction and thus reducing potential competition. The extensions of the ice shelves during glaciations in the past may have favoured the use of the fine fraction, allowing only those species to survive that did not need to live on freshly sedimenting organic matter from blooms.

So after all, Hedgpeth`s paradox may not exist; despite the seasonal restriction of pelagic primary production sufficient food seems to be available. But does this mean the phytoplankton blooms are without importance for the benthos?
Certainly not. They obviously contribute substantially to the energy flow within the pelagic system, on the one hand passing via their grazers -copepods, euphausiids, salps- to the top predators, including birds, seals, whales, fish and squid. And on the other hand, after fuelling these food chains and sinking as pellets, or just sedimenting when the bloom dies, the algae and their grazers, via resuspension and advection, contribute to the near-bottom detritus chain that is available to the benthos all year round.

\section{"Reproduction of Antarctic benthic fauna is predominantly tied to the plankton blooms"}

The extreme seasonality of Antarctic light conditions and of the bloom system also led to a widespread paradigm that benthic reproductive strategies should be tied intimately to this seasonality, i.e. species should set free their eggs, larvae or young in a way that they could feed optimally on the plankton blooms (in case of pelagic planktotrophic larvae, see next chapter) or on the sedimenting particulate matter when the blooms finish. In temperate regions, this strategy seems to apply widely, i.e. benthic species spawn predominantly in late spring in accordance with the larger plankton bloom during this season (e.g., Bosselmann, 1989, 1991). The principal difficulty to study these relations in Antarctic waters is that most benthos-related cruises take place in summer or autumn, with only scarce information available for the rest of the year.

Despite these problems, a considerable amount of new information has accumulated recently on the timing of reproduction in (mostly high-) Antarctic waters. For the period before the EASIZ cruises, which started in 1996, it has been summarized in Arntz et al. (1992).

Spawning of the gorgonian Thouarella variabilis occurs presumably during Antarctic summer and the swimming planulae settle soon after release (Brito et al., 1997). Larvae have been found so far only in the gastrovascular cavities of the polyps of Fannyella rossii, F. spinosa and Thouarella sp. (Orejas, 2001). The gorgonians Ainigmaptilon antarcticus and Dasysthenella acanthina presented large oocytes (Orejas et al., subm. b, c). The development of the first feeding polyp in gorgonians (and possibly also in other sessile invertebrates) may last longer in polar regions than previously assumed (Orejas et al., subm. c), indicating that only the functional polyp may profit from the plankton blooms in the 
favourable season. So the coupling with the period of high primary production is indirect in this group, via a lecithotrophic larval stage in winter which can be either brooded, demersal or pelagic, depending on the species.

In bivalves, continuous reproduction seems to be a common pattern. Of the species studied in the eastern Weddell Sea, 17 were identified as brooders supplying their young up to a small adult stage whereas the reproductive mode of the others revealed no distinct seasonal patterns (Hain, 1990; Hain and Arnaud, 1992). These are largely uncoupled from seasonality, as should be also the 13 species assumed to have demersal lecithotrophic larvae, whereas the remainder -presumably also demersal but with planktotrophic larvae?- might make use of seasonal production. This could be the case, too, with the suspected pelagic larvae of the common shallow-water bivalves Yoldia eightsi and Adamussium colbecki (Clarke, 1992; Chiantore et al., 2000) whereas the pelagic stage of Laternula elliptica (see below) must be considered independent. Metamorphosis in egg capsules makes most gastropods independent of plankton blooms. Pelagic planktotrophic larvae were found only in two families (Capulidae: Echinospira; Lamellariidae: Limacosphaera), however, the latter larva is also partly independent as it can switch to lecitotrophic feeding if food becomes scarce (Hain and Arnaud, loc. cit.). Another species where the reproductive cycle may be coupled to plankton blooms is the shallow-water limpet Nacella concinna, with a pelagic planktotrophic larva (Picken, 1980).

During the EASIZ III cruise, considerable reproductive activity in autumn was found in many molluscs. Larger bivalve specimens often had welldeveloped gonads, brooding chitons were carrying juveniles, and gastropod egg-masses contained juveniles ready to hatch (Arntz and Brey, in press).

The common Antarctic caridean shrimps Chorismus antarcticus and Notocrangon antarcticus attach their spawned eggs in summer (January, February) to the pleopods, from where they hatch in the following late spring and summer (November to February), thus enabling an encounter of the larvae with the blooms. These species spawn only every second year. Larvae of the third common shrimp, Nematocarcinus lanceopes, and of other rare species have never been found, but $N$. lanceopes females are known to migrate to shallow waters towards spring, with juveniles occurring there during the bloom period (Gorny et al., 1992). During EASIZ III, berried females of Notocrangon antarcticus were found at $200 \mathrm{~m}$ depth, and advanced decapod larvae (zoea 4) of an as yet undetermined species appeared close to the seafloor.

Most amphipods and possibly, the majority of the peracarids seem to be uncoupled from the spring and summer blooms not only because of brooding their young in a marsupium (as they do in other regions) but also due to their enormous range of feeding types (De Broyer, in press; Klages and Gutt, 1990; Coleman, 1991) including many scavengers (Arnaud, 1970), predators and specialists. Highly advanced juveniles have been registered in the marsupia of freshly caught amphipods and in aquaria mainly in autumn (Klages, 1993). During EASIZ III $>50 \%$ of the free-living species contained eggs in their marsupia in autumn. Freshly hatched amphipods were found of the species Paraceradocus gibber, Liljeborgia georgiana (many already with empty marsupia) and Eusirus sp. (Rauschert, pers. comm.). Adult females of the amphipod commensals in sponges and ascidians were mostly bearing eggs.

Among holothurians, two different cases were described by Gutt et al., (1992). Psolus dubiosus did not reveal any seasonal differences in the ovaries which always contained two or three size classes of eggs; nor did the juveniles brooded between the tentacles show size differences between summer and winter. Conversely, Ekmocucumis steineni contained mature eggs in late winter (October) but not in summer (January/February), i.e. its reproduction is obviously coupled with the spring bloom period.

Off Signy Island, the sea urchin Sterechinus neumayeri has a very narrow temporal window, depending on water temperature, to produce viable larvae. Food availability and predation during the pelagic phase did not seem to be decisive factors for the sea stars Odontaster validus and $O$. meridionalis which release their larvae in winter (Stanwell-Smith and Peck, 1998).

Groups with highly advanced larvae or very young juvenile stages found in autumn during the EASIZ III cruise included polychaetes, isopods, regular and irregular echinoids, asteroids, and crinoids. Four species of asteroids were found brooding their young off the South Shetland Islands (Arntz and Brey, in press).

There is clearly no uniform pattern in the degree of coupling of Antarctic invertebrate reproduction to the extreme seasonality of primary production in this environment, although uncoupling seems to pre- 
vail, and the percentage of largely uncoupled species seems to be higher than in temperate latitudes. Uncoupling from the primary production cycle may be advantageous both on evolutionary time scales (because it should be easier to overcome glaciation periods when the ice shelves and the pack ice are extended, and open water blooms are scarce) and on seasonal scales (when short bloom periods lasting perhaps 8 -or as at Signy, up to 12 - weeks a year are followed by a much longer period with no major input). The reasons why there is uncoupling are not always easy to understand (see discussions in Pearse, 1994; Poulin and Féral, 1996; and StanwellSmith and Peck, 1998). However, the intuitive feeling that it would mean a considerable waste if the blooms of primary production were not fully utilized to build up gonadal tissues and to invest in species offspring is not so mistaken, after all: Lack of direct use does by no means preclude indirect use via seston, resuspended material etc., with the advantage that these food sources are available to larvae, postlarvae and juveniles year round and can be advected from ice-free waters over quite a distance.

\section{"Meroplanktonic larvae are almost non-existent in Antarctic waters following Thorson's rule"}

Few subjects have originated such an amount of controversial discussion in recent decades as the question of a latitudinal gradient in the occurrence of pelagic planktotrophic larvae, supposedly from an overwhelming dominance of this reproductive strategy in tropical waters to its near disappearance under polar conditions. This hypothesis, based on the work of Thorson $(1936,1946,1950)$ but labelled as "Thorson's rule" only by Mileikowsky (1971), has -as many other paradigms of this kind- quite a convincing background of argumentation: Compared with year-round (although often low, if upwelling areas are excluded) production and fast larval development in the tropics due to high water temperatures, polar areas have an innate deficiency in that they are providing large algal blooms only during a short season (see above) and prolonging, at the same time, larval development enormously (see, for example, Hain and Arnaud, 1992; Stanwell-Smith and Peck, 1998). From the work of RV Polarstern we might add that due to extreme transparency of high Antarctic waters during the long winter season $(79 \mathrm{~m}$ Secchi disc depth, Gieskes and Veth, 1987), life should also be very dangerous for a larva which has to survive in these waters for a long time.
We do not want to examine in detail all the misunderstandings that have apparently been involved in dealing with the tendency labelled as Thorson's rule and have made an objective judgement difficult. There may as well have been certain flaws in the treatment of the original data either by Thorson or by Mileikowsky (Pearse, 1994). On the other hand, both Mileikowsky and Thorson did distinguish between planktotrophic and lecithotrophic larvae (see Mileikowsky, 1971: pelagic larvae are meant to be planktotrophic), however they obviously considered all lecithotrophic larvae to be demersal. The larval question is sometimes discussed without considering all the other well-known characteristics of benthic invertebrates in polar regions which are intimately connected to it (latitudinal clines in egg number and size, slow embryonic development, deferred first maturity, longevity, etc.), which does not make much sense (Arntz et al., 1994, Poulin and Féral, 1996). We will not repeat here the detailed discussions in the literature on the different classifications of larvae from an ecological and embryological point of view (cf. Poulin et al., 2001: p. 112), the evolutionary reasons for, and the advantages or disadvantages associated with direct or indirect development strategies (see, e.g. Olson and Olson, 1989; Pearse, 1994; Poulin and Féral, 1994, 1996; Bhaud et al., 1995; Todd, 1998; Pechenik, 1999). We would just like to concentrate on the question whether or not pelagic, in particular planktotrophic, larvae are less common or less important under polar conditions.

What do we know about meroplanktonic larvae in the Southern Ocean? Obviously very little. Up to the present day, plankton catches do not yield much information because the nets are either too widemeshed or too fast to catch the tiny, fragile larvae in a satisfactory manner. Furthermore, most plankton nets do not approach the seafloor very closely to avoid damage, whereas many meroplanktonic larvae and drift stages have a tendency to cling close to the bottom. We are still waiting for a functioning plankton suctor to be used from research vessels in deeper waters. So most of the available information stems from shallow-water investigations close to Antarctic stations.

Already the scientists of the Challenger cruise stated that meroplanktonic larvae are much less conspicuous in the Antarctic plankton than in other regions of the world ocean (Clarke, 1992). Although this statement, which has been confirmed in recent investigations (Stanwell-Smith et al., 1999), refers 
to abundances (see below) rather than to species richness, it reflects the non-optimal polar conditions which are the underlying argument for Thorson's rule. On the other hand, the absolute number of meroplanktonic larvae known from Antarctic waters has been increased recently by various studies. The two-year study of Stanwell-Smith et al. (1999) at Signy Island has made the most important contribution. These authors investigated the near-bottom water, also under the pack ice, using a narrowmeshed net towed by divers and a suctor. In total, they found 131 different larval types which are probably not all species because in some cases they might represent successive stages of one species. On the other hand, larvae of some species may be so similar that this might have led to an underestimation. Meroplanktonic larvae off Signy Island occurred the year round, however with changes in the dominance of major taxa. Annelid trochophorae dominated in summer, echinoderm larvae and gastropod veligers in winter, whereas planulae of different groups were found all year.

The Signy study of Stanwell-Smith et al. (1999) has provided by far the highest number of pelagic larvae from Antarctic waters. Former publications never mentioned more than 20 larval types (Pearse et al., 1991; Arntz et al., 1994). However, only for few species (also in the Signy case) the feeding mode is known. So how many of these larvae are planktotrophic? The best studied groups are molluscs, crustaceans, and echinoderms; information on all other groups is sadly incomplete.

Of 44 bivalve species studied in the Weddell Sea, 17 were brooders (Hain and Arnaud 1992). 13 bivalve species seemed to have lecithotrophic and 14 species planktotrophic larvae. However, all of these are supposed to live demersally; no pelagic bivalve larvae have been found in the Weddell Sea. Of 18 prosobranch and opisthobranch gastropods, 15 showed intracapsular metamorphosis with very long embryonic development. Late veliger stages hatching from a gelatinous egg mass were found in the opisthobranch Philine alata. They were able to drift in the aquarium for up to two days. Only two types of meroplanktonic larvae were detected in the Weddell Sea. The small Echinospira larva of Capulus subcompressus is truly planktotrophic, whereas the Limacosphaera larvae of two Marseniopsis species can switch from their own resources to plankton and live for more than a year in the pelagial. Finally, a few lecithotrophic larvae were found by Hain and Arnaud (1992) belonging to Solenogas- tres and to the polyplacophoran Nutallochiton mirandus; neither of them obviously leaves the seafloor for any length of time. Of two monoplacophoran species in the high Antarctic, one was found to be a brooder whereas the other one did not reveal its reproductive mode.

The Weddell Sea shelf molluscs studied by Hain and Arnaud (1992), as a group, do not represent a very convincing case for refuting Thorson's rule, not even the bivalves. Interestingly however, in shallow Antarctic waters some very common species such as Yoldia eightsi and Adamussium colbecki are suspected to have pelagic planktotrophic larvae (see above); a well-known (but proven) case in the Arctic is Mya truncata. Laternula elliptica, also with a pelagic stage, hatch from egg capsules as advanced juveniles (Bosch and Pearse, 1988).

Of 22 echinoderms investigated at McMurdo, 11 had pelagic lecithotrophic larvae, 5 species had pelagic planktotrophic larvae, and 6 had a nonpelagic development (Pearse, 1994). Asteroids do not follow Thorson's rule although brooders are not uncommon (own obs., 4 species- from EASIZ III). On the other hand, of the 60 Antarctic echinoid species known only 16 (among them all 5 Echinidae) were found to have pelagic larvae, 39 are brooders. The larvae of 5 cidaroids (otherwise brooders) are as yet unknown (Poulin and Féral, 1996). Some very common shallow-water species have pelagic planktotrophic larvae: the sea stars Odontaster validus and $O$. meridionalis as well as the sea urchin Sterechinus neumayeri (StanwellSmith and Peck, 1998). Sterechinus neumayeri has a very narrow temporal window (dependent on water temperature) to produce viable larvae.

While Arctic ophiuroids have a tendency to reproduce via pelagic ophiopluteus larvae (Piepenburg, 2000), no information seems to be available on Antarctic species, and the same is true for holothurians (see below). Pentacrinus larvae were found attached to crinoids in autumn 2000 (Bohn, pers. comm.) in the SE Weddell Sea.

Peracarid crustaceans including the most speciose taxon in Antarctic waters, the amphipods (De Broyer and Jazdzewski, 1996) are all brooders, like in other oceans. Of the decapods only the caridean shrimps and the lithodid crabs are represented south of the Polar Front. The two common shrimps Chorismus antarcticus and Notocrangon antarcticus have pelagic planktotrophic larvae of very short duration (Bruns, 1992) whereas larvae of the third common (benthopelagic) species Nematocarcinus 
lanceopes and some rarer species have not yet been detected. Lithodid crabs in the Beagle Channel seem to reproduce by means of demersal larvae (Lovrich, 1999); to our knowledge larvae of those living south of the Convergence have not yet been studied.

In many Antarctic polychaetes living in tubes such as terebellids, and in Paronuphis antarctica, a common reproductive strategy is to retain early developmental stages of larvae in the tubes. Unexpectedly, two Polynoidae of the genus Hermadion were found to be brooding species. Even within polychaete species with small egg sizes, there seems to be a tendency to avoid planktonic phases. Fully formed juveniles were found on the setae of a 1-mm long euphrosinid worm (Piraino and Montiel in Arntz and Brey, in press). Sabellids exhibit very variable reproductive features ranging from asexual reproduction via brooding to free-spawning species (Gambi and Patti, 1999), the latter presumably with demersal larvae.

Worldwide, the great majority of the typical epifaunal taxa sponges, bryozoans and ascidians reproduce by means of short-lived pelagic lecithotrophic larvae (Todd, 1998). However, frequent development of buds in Antarctic sponges under certain conditions (P. Dayton, N. Teixidó, pers. comm.) might indicate asexual reproduction in this group. Of five octocoral species studied in the eastern Weddell Sea, three (Thouarella sp., Fannyella rossii, $F$. spinosa) were definitely found to be brooders; in the two others (Ainigmaptilon antarcticus, Dasysthenella acanthina) the reproductive mode remained unknown due to the lack of larvae in the polyps (Orejas, 2001). However, the large oocytes found in these species and the long duration of the oogenesis do not principally preclude a brooding incubation mode. Conversely, Thouarella variabilis produces swimming planulae at King George Island (Brito et al., 1997).

So while the number of pelagic larvae found in the Southern Ocean is slowly increasing due to increased research effort, an elevated share of brooders or species with a demersal development mode is confirmed at the same time (Poulin and Féral, 1996), and we are still very far from final conclusions as to the validity of Thorson's rule in the Southern Ocean. But is our knowledge much better for temperate or Arctic latitudes? Apart from Thorson's classic study on the meroplankton of temperate Danish waters, in which he describes 160 larval types (Thorson, 1946), nobody seems to have attempted to arrive at a complete inventory. Ockelmann (1962), also from the Helsingør laboratory, published a detailed study on latitudinal gradients of different larval types of bivalves along the European coasts (Fig. p. 33). Bosselmann (1989), in a two-year study on benthic recruitment in the North Sea, found at least 36 pelagic larvae in an area relatively poor in species, however without indicating their feeding mode. Riedl (1966), in his investigation of submarine caves in the Mediterranean, reported various types of meroplanktonic larvae (Fig. p. 470), but did not provide information on their relative share as compared with other reproductive strategies. This study is a good example to what extent the duration of pelagic larval phases can vary within the same environment.

From boreal and Arctic waters Mileikowsky (1968) reported 70 pelagic larvae whereas Thorson (1936) had found only 12 in East Greenland. This latter figure has been raised to 42 (Andersen, 1984: North Greenland) and 45 (Smidt, 1979: Southwest Greenland), respectively, while Schlüter (1998), in a shorter shipboard study, found 27 larval types in the Barents Sea east of Svalbard. The species richest larval taxon in these studies were annelids followed by molluscs and echinoderms. A strong influence of Atlantic water masses seems to transport meroplanktonic larvae into the area (Schlüter, 1998). Furthermore, the "pelagic larvae" also include lecithotrophic larvae of the demersal type. So while it is clear that Thorson's original figure of pelagic larval occurrence was too low, published recent information still does not facilitate a clear separation into pelagic planktotrophic larvae and other types.

Reliable figures from the tropics are even scarcer (Stanwell-Smith et al., 1999). In warm water, larval life is much shorter, which combined with regionally extremely high species richness (Crame, 2000 a,b) does not make the task of assigning larvae to different modes easier.

In terms of abundance which oscillated between 10 and 30 meroplanktonic larvae $\mathrm{m}^{-3}$, Mya truncata was dominant (39\%) in the Schlüter study, followed by annelids (31\%) and echinoderms (24\%). In another investigation in the Northeast Water Polynya off East Greenland, Clough et al., (1997) mostly found abundances around 10 larvae $\mathrm{m}^{-3}$, too, but in the centre of an eddy they increased to 84 larvae $\mathrm{m}^{-3}$.

Meroplanktonic larvae during the Bosselmann (1989) North Sea study mostly maintained abundance values above 100 larvae $\mathrm{m}^{-3}$ from spring to autumn, in about one-third of the cases they exceeded 1000 larvae $\mathrm{m}^{-3}$ with a maximum figure of about 
3000. Benthic recruit stages of these species occurred in about an order of magnitude higher values $\mathrm{m}^{-2}$. The maximum was reached by the bivalve Tellina fabula with 212,000 recruits $\mathrm{m}^{-2}$. Abundances in the tens of thousands $\mathrm{m}^{-2}$ are a normal feature in the North Sea (Niermann, 1990).

Conversely, the abundances registered by Stanwell-Smith et al., (1999) off Signy Island are several orders of magnitude lower than in temperate latitudes. Even the comparatively high values of encapsulated pelagic larval stages of the broadcasting bivalve Laternula elliptica (Bosch and Pearse 1988), up to $50 \mathrm{~m}^{-3}$, and the successive juvenile recruits $\left(7600 \mathrm{~m}^{-2}(\right.$ ?)), are clearly below temperate values. "Rather than by large pulses of larvae... strongly influenced by oceanographic features during their short life span" (as in tropical areas) "the Southern Ocean is characterized by a year-round but low abundance of long-lived, slow-developing larvae, with a consequent low level of year-round recruitment to new substrata." (Stanwell-Smith et al., loc. cit.).

So we remain with a few reliable news and many doubts. Thorson was right in assuming that the general importance of planktotrophic larvae in polar regions is lower if we consider, e.g. the high abundances $\mathrm{m}^{-3}$ and the subsequent recruit abundances $\mathrm{m}^{-2}$ in the North Sea. Only for a few groups, especially the gastropods, the rule has been confirmed on the taxon level. Recently Gallardo and Penchaszadeh (2001) introduced a new element into the discussion in suggesting that the rule is valid for this group only on the Pacific side of South America whereas gastropods do not follow it on the Atlantic side, where non-pelagic larvae prevail up to the subtropics because of different substrates.

We now know for sure that the absolute number of species with pelagic larvae in polar areas is higher than Thorson's assumption. We also know that some species are quite successful under present conditions in polar shallow water, with (sometimes even planktotrophic) pelagic larvae which may occur in fair abundance although never in numbers comparable to temperate latitudes. However, our present data appear to be very crude approximations in all areas due to methodological problems. We often do not know the larvae, and we cannot identify the feeding types without knowing the larvae (just considering the size of the embryo or yolk, or the juvenile shell, does not always help, see Clarke, 1992a, Hain and Arnaud, 1992 and Hoegh-Guldberg and Pearse, 1995). To make a valid comparison absolute numbers of meroplanktonic larvae are not much use; we would need to know percentages. What do absolute numbers of larval types tell us if we do not, at least roughly, know the number of species in the respective area? Thorson (1950) speculated that $80-85 \%$ of invertebrate benthic species should have planktotrophic pelagic larvae in the tropics, opposed to $55-65 \%$ in temperate waters, but it is difficult to find the base for these estimates, and some authors consider these values too high (Clarke, 1992; Pearse, 1994). However, the few other data available seem to indicate that planktotrophic larvae might indeed contribute a larger share towards lower latitudes. E.g., in Pearse's echinoderms they made up 23\% in McMurdo vs. $55 \%$ in California vs. $17 \%$ in Greenland, see Clarke 1992a; or in Ockelmann's bivalves $16 \%$ in Svalbard vs. $64 \%$ in the northern North Sea and $>80 \%$ on the English and French Channel coasts (Ockelmann, 1962). If this should hold true, nailing down Thorson and Mileikowsky to their use of the term pelagic (instead of planktotrophic) larvae would be splitting hairs, because the latter is what Thorson originally meant. However, as we will show below, we are only slowly approaching reliable estimates of species richness in many taxa for different regions, and it may take a long time before we can provide the percentages required for a meaningful discussion. Our conclusion is that we have to be very modest at this time judging on the validity of a latitudinal gradient in larval strategies as claimed by Thorson's rule.

\section{"Faunal species richness in the Southern Ocean should be low obeying to the bell-shaped curve of species distribution from the tropics to the poles"}

The paradigm of a bell-shaped distribution of benthic species richness along the latitudinal gradient, with high values at low latitudes decreasing towards low values at high latitudes, may be much older than its literature record. Any visitor to the tropics coming from cold or temperate regions is impressed by the richness of mollusc species scattered on many tropical beaches and the diversity of life forms in a coral reef. Furthermore, there seems to be a distinct gradient on the terrestrial side, from rich rain forests to the barren permafrost soils and snow-covered landscapes in polar regions. On the other hand, some marine taxa such as macroalgae clearly do not attain their maximum species richness in the tropics (Warwick 1995). So the subject has been under discussion for some time (see, e.g. 
Clarke 1992 b; Arntz et al., 1997; Crame 2000a,b; Gray 2001a,b).

Before turning to recent observations in the southern hemisphere which might shed some new light on the subject, we would like to ask a nasty question: Why should there be a latitudinal gradient at all? Latitude by itself is not an ecofactor. Stable day length as opposed to a highly variable light regime during the year, warm water vs. cold water, continuous low production vs. seasonal production pulses, predominantly benign conditions vs. frequent and drastic physical disturbance - are these characteristics of tropical regions (as compared to those of higher latitudes) necessarily inducing higher biodiversity? Obviously calcification is favoured in warm water, and the long existence (not the stability) component of Sanders`stability-time hypothesis may have been favourable for the development of co-existence of many species in the tropical warm water belt, which is much older than either polar region (Crame 2000a), but that is about all we know.

On the other hand, along all continents except the Antarctic (where circumantarctic conditions are essentially the same) environmental conditions vary to an extent which makes valid comparisons very difficult. For example along the South American Pacific and Atlantic coasts, conditions are similar (tropical) only in the extreme north. Tropical conditions, modified by enormous river runoff prevail off Brasil. Conversely, the Humboldt current upwelling off Peru and the northern half of Chile combines cool water and very high surface- and shallow-water productivity (but moderate species richness) with an extensive oxygen minimum zone between 30 and $700 \mathrm{~m}$ depth, where prokaryotic sulfur bacteria are almost the only life, contrasting with well-oxygenated waters off Uruguay and Argentina. Further south, the highly complex Chilean fjord system with interchanging rocky coasts and sandy beaches, and strong input from inland glaciers, has no counterpart on the Argentinian Atlantic coast although rocks may prevail there in shallow water, as well. There is no reason whatsoever to expect simultaneous latitudinal changes in shallow-water species richness along the two coastlines. The same is true for comparisons within many areas of the tropics, where barren sandy beaches and hypersaline lagoons, both governed by strong environmental fluctuations and characterized by very low species richness, contrast with coral reefs and subtidal bottoms which represent the other extreme.

A second problem which impedes valid comparisons is the methodology applied by investigators all over the world, not only the use of totally different equipment (Warwick, 1995; Arntz et al., 1997) but also the use of inappropriate scales, insufficient data volume and inadequate analytical methods (Gray, 2001a,b). This problem, despite its being well documented in the literature, has hitherto caused very little change in behaviour, badly needed if comparisons are to improve. This is why we will mostly use overall regional species numbers compiled from the literature, which may represent the most reliable data at present.

What do we know about species richness in the southern hemisphere, especially in the Antarctic and the regions close to it, and how do these compare with other regions?

The investigators who contributed to creating the concept of the bell-shaped curve, e.g. Sanders (1968, soft-bottom macrobenthos); Thorson (1957, hard-bottom epifauna, esp. gastropods), and Stehli et al. (1967, bivalves), based their idea -as did many others following them- on very small sample sizes (Gray, 2001a) and had no data available from the extreme south. These have been accumulating during the last few decades, as can be seen from the increase of species numbers presented successively for various macrobenthic groups by Dell (1972: Table I), White (1984: Table III) and Arntz et al., (1997: Fig. 1.1 A). According to the latter compilation, the actually known number of macrobenthic invertebrates in Antarctic waters may be assessed at about 5000 (Gray 2001a: Table 2). This value has to be used with caution as it may be including, in many taxa, species living north of the Polar Front, i.e. in Subantarctic waters.

For the eastern Weddell Sea alone (only shelf and slope) the EASIZ I cruise yielded about 1200 macrofaunal species by close cooperation among specialists on board and a thorough check of trawl catch remains by taxonomists of the St. Petersburg Zoological Institute (Gutt et al., 2000). The true number of species must be distinctly higher because towed gear is not an ideal instrument for this fauna. Still, this species richness appears to be in the same order of magnitude as that derived from larger studies in the North Atlantic (Gray 2001a: Table 1) and the Mediterranean Sea (Fredj and Laubier, 1985). Areas with a distinctly lower species richness are the Baltic (Arntz, 1971) and the North Sea (Daan and Mulder, 2000), and the Peruvian Humboldt upwelling (Tarazona et al., 1988; Tarazona and Valle, 1999). All these seas cover, however, a much smaller area. 
For the EASIZ III cruise a similar approach was used, yielding species number per trawl haul for the different groups. These data can be used for comparisons with other areas. Species number per haul was several times higher than in the Arctic Laptev Sea (Sirenko et al., 1997), the North Sea or the Baltic (own obs.).

Species-area comparisons as those made by Gray (2001a: Table 1) represent (mainly?) infaunal communities. For the Weddell Sea shelf and slope and the Antarctic Peninsula we also have quantitative infaunal data from the multibox corer (Gerdes et al., 1992; Piepenburg et al., in press; Gerdes pers. comm.). These data provide additional information to the species-rich epifaunal communities of the high Antarctic, which contribute most to the total species number in that area. The taxonomic analysis of the infaunal data has not yet been completed, but our impression is that whereas species richness of the high Antarctic epibenthic communities is very high, that of infaunal communities in this area is much lower, and might yield quite a different picture in terms of a latitudinal cline. Around the Antarctic Peninsula the infauna is richer in biomass and, presumably, also in diversity (see, e.g. for polychaetes, Gallardo et al., 1988).

A comparison with the area closest to the Antarctic and which separated last, the Magellan region, reveals that most taxa increase in species richness towards the Antarctic (for details see Arntz and Ríos, 1999), i.e. do not follow expectations if the bell-shaped curve was valid. This tendency is particularly obvious in sponges, bryozoans, polychaetes, peracarid crustaceans, pycnogonids and many echinoderms. For example amphipods, the most speciose macrofaunal taxon in the Southern Ocean, increase from (actually described) 232 species in the Magellan region to 391 in the Subantarctic and 531 in the Antarctic (De Broyer and Jazdzewski, 1996). On the other hand, some groups (hydrozoans, molluscs) reveal little difference between the two areas, and a few actually decrease (decapods, stomatopods, acorn barnacles). Barnes and De Grave (2001) studied the encrusting fauna along this gradient, which is not directly comparable with our data.

As this is only the "tail" of the southern hemisphere curve, we might -still in very crude terms, i.e. total species registered- look further north. In two recent publications on bivalve species richness (Crame 2000a,b) confirmed the tropics as diversity centres of this group and centres of evolutionary innovation, but found the latitudinal clines less regular in form than was once imagined. In the south- ern hemisphere Australia forms a distinct diversity hotspot besides strictly tropical foci in the South China Sea, the Caribbean and the Panamic region in the Pacific. Crame stresses the importance of the historical context involving a warmwater history of at least $60 \mathrm{Ma}$, i.e. 2-3 times longer than the coldwater history of the Antarctic. At a recent macroecology meeting in Chile (summarized by Wieters, 2001) Roy stated that mollusc species richness along both coasts of the Americas is highest in the tropics, declining drastically poleward (to which latitude?). Conversely, Valdovinos et al. found molluse diversity in the SE Pacific to increase dramatically south of $42^{\circ} \mathrm{S}$ due to greater habitat complexity. Litoral fish diversity again decreased south of $42^{\circ} \mathrm{S}$ for historical reasons (Ojeda). Finally, Fernández et al. emphasize that the larval type of invertebrates may influence species richness: those with planktotrophic larvae corresponded to the bell-shaped distribution along the Pacific coast whereas those without did not (for details see Wieters, 2001). The extraordinary complexity of the $4200 \mathrm{~km}$ Chilean coast (Fernández et al., 2000), mentioned already above, may explain in part the conflicting evidence for different taxa. Lancellotti and Vásquez (1999) refer to almost 1600 benthic species described for $<100 \mathrm{~m}$ water depth between 18 and $48^{\circ} \mathrm{S}$, which would indicate a fairly high overall species richness because there is quite a diverse fauna below the oxygen minimum zone (own obs., Sonne cruise 2001).

Many authors have dealt with the subject of latitudinal diversity clines in recent years, arriving in general at the conclusion that in the marine realm there may be a latitudinal gradient as hypothesized by the bell-shaped curve in the northern hemisphere at least for some taxa, but there is very contradictory evidence for such a pattern in the southern hemisphere. The dominance of the tropical belt as a whole in terms of total species richness seems to be beyond doubt, but this may be due to the preponderance of calcareous organisms, and there appear to be substantial differences in individual groups. What we definitely know is that most marine taxa show an unexpected increase from the Magellan region towards the Antarctic. We are not sure whether the (old, isolated) Antarctic is really much richer in benthic species than the (young, shallow-connected) Arctic as suggested by many authors; very few publications address the bipolar diversity comparison directly (e.g., Jazdzewski et al., 1995 for shallow water).

A final point we would like to raise is, how confident can we be of our species richness data? Clearly, 
we have much more material available than those scientists who developed the ideas on latitudinal gradients (see Gray's Table, above); however, the origin of the data is most heterogenous. They can be derived from large individual stations, random sampling over large distances, transects, time series, not to speak of different gear, taxonomic problems in the breakdown to species or analytical difficulties. To arrive at final conclusions on latitudinal clines in diversity we will have to unify concepts, sampling strategies and gear. However, is there reason to believe that at least our global species richness data derived from all available sources are more or less trustworthy?

Our answer might be affirmative for European waters; despite sibling species, invaders and other uncertainties our inventory of benthic macrofauna should be fairly complete at least for the continental shelf. Hayward and Ryland (1995, fide StanwellSmith et al., 1999) mention about 1500 marine invertebrate (macrofaunal?) species for NW Europe. The southern North Sea and the western Baltic belong to the areas with a low species richness. When the first author collected samples for his dissertation over one year, sampling 24 stations between 7 and $30 \mathrm{~m}$ in Kiel Bay every second month, he collected a total of 110 species from almost 50,000 individuals (Arntz, 1971). This species number might have been raised to ca. 150 species including the very shallow areas in the Baltic. Monitoring the Dutch sector of the North Sea, Daan and Mulder (2000) required only about 10,000 individuals from 3-51 m to collect more than 200 species, still a rather low number. However, when Zettler et al. (2000) summarized the macrobenthic species ever encountered in Mecklenburg Bay (east of Kiel and with an even more reduced fauna due to lower salinity), they registered 223 species while Gerlach (2000), doing the same for Kiel Bay, arrived at 700 species (registered in 135 years). These areas are extremely well studied whereas in the Southern Ocean we are not even sure whether the fauna is circumantarctic. The significance of these comparisons for true Antarctic diversity is obvious. Another example are seamounts (Richer de Forges et al., 2000): 72\% of the macrofaunal species registered hitherto from seamounts come from only five of them; the estimated number of seamounts worldwide is 30,000 .

We conclude that also concerning the bell-shaped curve of species richness there is evidence for pros and contras. This is not surprising taking into account our preliminary data bases and the amount of regional complexity involved. There is, however, good rea- son not to simply "dismiss" the concept. In fact the issue of changing species numbers along latitudinal gradients is everything but an academic question, because -beyond the global climate change question which obliges us to care for baseline data- it urges us to look for the causes of distributional gradients, i.e. the processes and mechanisms behind these distributions. A good example in this context is the contention of Frederich et al., (2000) who argue that the inability of reptant decapods to regulate the high amount of $\mathrm{Mg}^{2+}$, an anaesthetic at very low temperatures, in their haemolymph prevents this taxon from recolonizing high Antarctic waters.

\section{CONCLUSION: CONCEPTS CHANGE, BUT SOME OLD ELEMENTS USUALLY REMAIN VALID}

The overview of some Antarctic-related problems given here, which could easily be extended, demonstrates that indeed there have been profound changes in basic concepts dealing with the Southern Ocean ecosystem. Besides that it also shows, however, that in most cases there are parts of the old concepts which seem to be worth maintaining. There is no reason to put out the baby with the bathwater! Instead, we need more of the intuitive kind of ecologists such as Margalef because the next level of applicants will not be missing, nibbling at the concepts and thinking, each generation anew, they know the definite truth. That this is not likely to be the case is the third result of our recapitulation, indicating that much of our recent information is still rather soft and, above all, very incomplete to dare to come up with final conclusions. How can we arrive at such conclusions on Southern Ocean species richness if we are not even sure that the benthos is really circumpolar? How can we compare the importance of planktotrophy in different parts of the world ocean without knowing what percentage of the total fauna, or of certain taxa exhibit this larval strategy? How are we going to finish the discussion on the strategies of invertebrate larvae if we have no idea whether all these presumably lecithotrophic stages spend a few hours or two years in the plankton, if they are planktonic at all and not demersal, functioning as drifting stages or creeping around their parents? Can we really extrapolate from the known feeding habits of half a dozen suspension feeders to the trophic behaviour of those highly diverse, three dimensional assemblages that we have in mind when talking about the rich Antarctic benthos? 
Of course we have to place our observations, as preliminary as they may be, into a conceptual framework which reflects present knowledge, both as a work frame and discussion base for ourselves and our colleagues, and as a base for teaching the students. For the latter purpose it may be necessary to emphasize certain extremes to let them appear in a clearer, black-and-white fashion. A nice example is the concept of $\mathrm{r}$ and $\mathrm{K}$ strategy (which is also being torn to pieces these days), where the two extremes hardly ever occur in a pure fashion (what, by the way, the creators of this concept used to say from the beginning) -but they serve very well to illustrate the concept. If you look into the great textbook Ecología of the gentleman we are celebrating here today, you will find numerous examples of this kind, and there are millions of Spanish-speaking students on this planet who have got an excellent education in ecology through that book. I am pretty sure not a single one of these persons is suffering from the fact that many of the paradigms and concepts in that volume are no longer en vogue today. Some day someone will perhaps do an update, hopefully being as conscious as was Margalef that this will mean another preliminary step on the way to final truth. Scientific progress is in no ways only promoted by concepts which finally turn out to be true. Or, as C.A. Butman wrote in 1987:

"When seemingly conflicting assertions are closely scrutinized, they may all be valid replies but, in fact, to different questions".

\section{ACKNOWLEDGEMENTS}

The first author would like to thank the Spanish organizers for their invitation to present this keynote. Both authors are grateful to Juan Tarazona (Peru) for his comments on the manuscript.

\section{REFERENCES}

Alongi, D.M. - 1990. The ecology of tropical soft-bottom benthic ecosystems. Oceanogr. mar. Biol. ann. Rev. 28: 381-496.

Alvà, V., C. Orejas and M. Zabala. - 1997. Feeding ecology of Antarctic cnidarian suspension feeders (Hydrozoa, Gorgonacea, Pennatulacea). In: Arntz, W.E. and J. Gutt (eds.), The expedition Antarktis XIII/3 (EASIZ I) of Polarstern to the eastern Weddell Sea in 1996. Ber. Polarforsch. 249: 14-16.

Andersen, O.G.N. - 1984. Meroplankton in Jøergen Drøenlund Fjord, North Greenland. Medd. Grønl., Bioscience 12: 1-25.

Arnaud, P.M. - 1970. Frequency and ecological significance of necrophagy among the benthic species of Antarctic coastal waters. In: M.W. Holdgate (ed.), Antarctic Ecology vol.1: 259267. Academic Press, London.

Arntz, W.E. - 1971. Biomasse und Produktion des Makrobenthos in den tieferen Teilen der Kieler Bucht im Jahr 1968. Kieler Meeresforsch. 27: 36-72.

Arntz, W.E. and T. Brey. - in press. The expedition Antarktis XVII/3 (EASIZ III) of RV Polarstern in 2000. Ber. Polarforsch.

Arntz, W.E. and C. Ríos. - 1999. Magellan-Antarctic: ecosytems that drifted apart. Sci. Mar. 63(Suppl. 1): 1-518.

Arntz, W.E., T. Brey and V.A. Gallardo. - 1994 . Antarctic zoobenthos. Oceanogr. mar. Biol. ann. Rev. 32: 241-304.

Arntz, W.E., T. Brey, D. Gerdes, M. Gorny, J. Gutt, S. Hain and M. Klages. - 1992. Patterns of life history and population dynamics of benthic invertebrates under the high Antarctic conditions of the Weddell Sea. In: G. Colombo, I. Ferrari, V. U. Ceccherelli and R. Rossi (eds.), Marine Eutrophication and Population Dynamics, pp. 221-230. Olsen and Olsen, Fredensborg.

Arntz, W.E., J. Gutt and M. Klages . - 1997. Antarctic marine biodiversity: an overview. In: B. Battaglia, J. Valencia and D. Walton (eds.), Antarctic Communities. Species, Structure and Survival, pp. 3-14. Cambridge Univ. Press, Cambridge.

Arntz, W.E., J. Tarazona, V.A. Gallardo, L.A. Flores and H. Salzwedel. - 1991. Benthos communities in oxygen deficient shelf and upper slope areas of the Peruvian and Chilean Pacific coast, and changes caused by El Niño. In: Tyson, R.V. and T.H. Pearson (eds.), Modern and ancient continental shelf anoxia. Geol. Soc. Spec. Publ. 58: 131-154.

Barnes, D.K.A. and A. Clarke. - 1995. Seasonality of feeding activity in Antarctic suspension feeders. Polar Biol. 15: 335-340.

Barnes, D.K.A. and S. De Grave. - 2001. Ecological biogeography of southern polar encrusting fauna. J. Biogeogr. 28: 359-365.

Barthel, D. - 1997: Presence of fluff in an Antarctic shelf trough, at $600 \mathrm{~m}$ depth. In: W.E. Arntz and J. Gutt (eds.), The expedition Antarktis XIII/3 (EASIZ I) of Polarstern to the eastern Weddell Sea in 1996. Ber. Polarforsch. 249: $16 \mathrm{f}$.

Bathmann, U., G. Fischer, P.J. Müller and D. Gerdes. - 1991. Shortterm variations in particulate matter sedimentation off Kapp Norvegia, Weddell Sea, Antarctica: relation to water mass advection, ice cover, plankton biomass and feeding activity. Polar Biol. 11: 185-195.

Bhaud, M., J.-H. Cha, J.C. Duchene, D. Martin and C. Nozais. 1995: Larval biology and benthic recruitment: New ideas on the role of egg-masses and modelling life-cycle regulation. Sci. Mar. 59 (Supl. 1): 103-117.

Bosch, I. and J.S. Pearse. - 1988: Seasonal pelagic development and juvenile recruitment of the bivalve Laternula elliptica in McMurdo Sound, Antarctica. Amer. Zool. 28: 89A.

Bosselmann, A. - 1989: Larval plankton and recruitment of macrofauna in a subtidal area in the German Bight. In: Ryland, J.S. and P.A. Tyler (eds.), Reproduction, Genetics and Distributions of Marine Organisms, pp. 43-54. Olsen and Olsen, Fredensborg.

Bosselmann, A. - 1991. Recruitment and postlarval growth of some macrozoobenthos species in the German Bight. Meeresforsch. 33: 141-158.

Brito, T.A.S., P.A. Tyler and A. Clarke. - 1997. Reproductive biology of the Antarctic octocoral Thouarella variabilis Wright and Studer 1889. Proc. $6^{\text {th }}$ Int. Conf. on Coelenterate Biology 1995: 63-69.

Bruns, T. - 1992. Experimentelle Untersuchungen zur Larvalentwicklung antarktischer Garnelen (Decapoda, Natantia). Dipl. Thesis Univ. Osnabrück: $129 \mathrm{pp}$.

Bullivant, J.S. - 1967. Ecology of the Ross Sea benthos. NZ Dep. scient. ind. Res. 176: 49-78.

Butman, C.A. - 1987. Larval settlement of soft-sediment invertebrates: the spatial scales of pattern explained by active habitat selection and the emerging role of hydrodynamical processes. Oceanogr. Mar. Biol. Ann. Rev. 25: 113-165

Cattaneo-Vietti, R., G. Bavestrello, C. Cerrano, E. Gaino, L. Mazzella, M. Pansini and M. Sarà. - 2000. The role of sponges in the Terra Nova Bay ecosystem. In: Faranda, F.M., L. Guglielmo and A. Ianora (eds.), Ross Sea Ecology. Italianantartide Expeditions (1987-1995), pp. 539-549. Springer-Verlag, Berlin.

Cerrano, C., S. Puce, M. Chiantore and G. Bavestrello. - 2000. Unusual trophic strategies of Hydractinia angusta (Cnidaria, Hydrozoa) from Terra Nova bay, Antarctica. Polar Biol. 23: 488-494. 
Chiantore, M., R. Cattaneo-Vietti, P. Povero and G. Albertelli. 2000. The population structure and ecology of the Antarctic scallop Adamussium colbecki in Terra Nova Bay. In: F.M. Faranda, L. Guglielmo and A. Ianora (eds.), Ross Sea Ecology, pp. 563-573. Springer, Berlin.

Clarke, A. - 1992a. Reproduction in the cold: Thorson revisited. Invert. Reprod. Developm. 22: 175-184.

Clarke, A. - 1992b. Is there a diversity cline in the sea? Trends Ecol. Evol. 9: 286 f.

Clarke, A. and R.J.G. Leakey. - 1996. The seasonal cycle of phytoplankton, macronutrients, and the microbial community in a nearshore Antarctic marine ecosystem. Limnol. Oceanogr. 41: 1281-1294.

Clough, L.M., W.G. Ambrose Jr., C.J. Ashjian, D. Piepenburg and P.E. Renaud. - 1997. Meroplankton abundance in the Northeast Water Polynya: insights from oceanographic parameters and benthic abundance patterns. J. Mar. Syst. 10: 343-357.

Colemann, C.O. - 1991. Comparative fore-gut morphology of Antarctic Amphipoda (Crustacea) adapted to different food sources. Hydrobiol. 223: 1-9.

Conlan, K.E., H.S. Lenihan, R.G. Kvitek and J.S. Oliver. - 1998 Ice scour disturbance to benthic communities in the Canadian high Arctic. Mar. Ecol. Prog. Ser. 166: 1-16.

Connell, J.H. - 1978. Diversity in tropical rain forests and coral reefs. Science 1: 1302-1309.

Crame, J.A. - 2000a. Evolution of taxonomic diversity gradients in the marine realm: evidence from the composition of recent bivalve fauna. Paleobiology 26: 188-214

Crame, J.A. - 2000b. The nature and origin of taxonomic diversity gradients in marine bivalves. In: E.M. Harper, J.D. Taylor and J.A. Crame (eds.), The Evolutionary Biology of the Bivalvia. Geol. Soc. London Spec. Publ. 177: 347-360

Daan, R. and M. Mulder. - 2000. The macrobenthic fauna in the Dutch sector of the North Sea in 1999 and a comparison with previous data. NIOZ-Rapport 2000-7, Den Burg/Texel: 89 pp.

Dayton, P.K. - 1990. Polar benthos. In: Smith, W.O. (ed.) Polar Oceanography, Part B: Chemistry, Biology, and Geology, pp. 631-685. Academic Press, London.

Dayton, P.K. and R.R. Hessler. - 1972. Role of biological disturbance in maintaining diversity in the deep sea. Deep-Sea Res. 19: 199-208.

Dayton, P.K. and G.A. Robilliard. - 1971. The benthic community near McMurdo station. Antarct. J. U.S. 6: 54-56.

Dayton, P.K., G.A. Robilliard and R.T. Paine. - 1970. Benthic faunal zonation as a result of anchor ice at McMurdo Sound. In M.W. Holdgate (ed.), Antarctic ecology, vol. 1: 244-258. Academic Press, London.

Dayton, P.K., G.A. Robilliard, R.T. Paine and L.B. Dayton. - 1974. Biological accommodation in the benthic community at McMurdo Sound, Antarctica. Ecol. Monogr. 44: 105-128.

Dearborn, J.H. - 1968: Benthic invertebrates. Aust. Nat. Hist., Dec. 1968: 134-139.

De Broyer, C, (in press). Amphipod feeding guilds. Polar Biol

De Broyer, C. and K. Jazdzewski. - 1996. Biodiversity of the Southern Ocean: towards a new sysnthesis for the Amphipoda (Crustacea). Boll. Mus. civ. St. nat. Verona 20: 547-568.

Dell, R.K. (ed.). - 1972. Antarctic benthos. Adv. mar. Biol. 10: 1216.

Dexter, D.M. - 1974. Sandy beach fauna of the Pacific and Atlantic coasts of Costa Rica and Colombia. Rev. Biol. Trop. 22: 51-66.

Fernández, M., E. Jaramillo, P. Marquet, C. Moreno, S. Navarrete, P. Ojeda, C. Valdovinos and J. Vásquez. - 2000. Diversity, dynamics and biogeography of Chilean benthic nearshore ecosystems: an overview and guidelines for conservation. Rev. chil. Hist. nat. 73: 629-662.

Fossing, H., V.A. Gallardo, B.B. Jörgensen, M.Hüttel, L.P. Nielsen, H. Schulz, D.E. Canfield, S. Forster, R.N. Glud, J.K. Gundersen, J. Küver, N.B. Ramsing, A. Teske, B. Thamdrup and O. Ulloa. 1995. Concentration and transport of nitrate by the mat-forming sulphur bacterium Thioploca. Nature 374: 713-715.

Frederich, M., F.J. Sartoris, W.E. Arntz and H.-O. Pörtner. - 2000. Haemolymph $\mathrm{Mg} 2+$ regulation in decapod crustaceans: physiological correlates and ecological consequences in polar areas. $J$. Exper. Biol. 203: 1383-1393.

Fredj, G. and L. Laubier. - 1985: The deep Mediterranean benthos. In: Moraitou-Apostolopoulou, M. and V. Kiortsis (eds.), Mediterranean Marine Ecosystems. NATO Conf. Ser. I Ecology, vol.8. Plenum Press, New York: 109-145.
Gallardo, C.S. and P.E. Penchaszadeh. - 2001. Hatching mode and latitude in marine gastropods: revisiting Thorson's paradigm in the southern hemisphere. Mar. Biol. 138: 547-552.

Gallardo, V.A., S.A. Medrano and F.D. Carrasco. - 1988. Taxonomic composition of the sublittoral soft-bottom polychaetes of Chile Bay (Greenwich Island, South Shetland Islands, Antarctica). Serie Cient. INACH 37: 49-67.

Gambi, M.C. and F.P. Patti. - 1999. Reproductive biology of Perkinsiana antarctica (Kinberg) (Polychaeta, Sabellidae) in the Straits of Magellan (South America): Systematic and ecological implications. In: W.E. Arntz and C. Ríos (eds.), Magellan-Antarctic: Ecosystems that drifted apart. Sci. Mar., 63(Supl. 1): 253-259.

Garrabou, J. - 1998. Applying Geographic Information System (GIS) to study the growth of benthic clonal organisms. Mar. Ecol. Prog. Ser. 173: 227-235.

Gerdes, D., M. Klages, W.E. Arntz, R.L. Herman, J. Galéron and S. Hain. - 1992. Quantitative investigations on macrobenthos communities on the eastern Weddell Sea shelf based on multibox corer samples. Polar Biol. 12: 291-301.

Gerlach, S.A. - 2000. Checkliste der Fauna der Kieler Bucht und eine Bibliographie zur Biologie und Ökologie der Kieler Bucht. In: Bundesanstalt für Gewässerkunde (ed.), Die Biodiversität in der Nord- und Ostsee, Band 1. Berichte BfG - 1247, Koblenz: $376 \mathrm{pp}$.

Gieskes, W.W.C. and C. Veth. - 1987. Secchi disc world record shattered. $\operatorname{EOS} 68: 123$.

Gili, J.-M. and R. Coma. - 1998. Benthic suspension feeders: their paramount role in littoral marine food webs. Trends Ecol. Evol. 146: 316-321

Gili, J.-M., V. Alvà, F. Pagès, H. Klöser and W.E. Arntz. - 1996. Benthic diatoms as the principal food source in the sub-Antarctic marine hydroid Silicularia rosea. Oceanogr. Polar Biol. 16: 507-512.

Gili, J.-M., R. Coma, C. Orejas, P López-González and M. Zabala. - 2001. Are Antarctic suspension feeding communities different from those elsewhere in the world? Polar Biol. 24:473-485

Gorny, M., W.E. Arntz, A. Clarke and D.J. Gore. - 1992. Reproductive biology of caridean decapods from the Weddell Sea. Polar Biol. 12: 111-120.

Graf, G. - 1989: Benthic-pelagic coupling in a deep-sea benthic community. Nature 341: 437-439.

Gray, J.S. - 1994: Is deep-sea diversity really so high? Species diversity of the Norwegian continental shelf. Mar. Ecol. Prog. Ser. 112: 205-209.

Gray, J.S. - 2000. The measurement of marine species diversity, with an application to the benthic fauna of the Norwegian continental shelf. J. exp. mar. Biol. Ecol. 250: 23-49

Gray, J.S. - 2001a. Antarctic marine benthic biodiversity in a world-wide latitudinal context. Polar Biol. 24: 633-641.

Gray, J.S. - 2001b. Marine diversity: the paradigms in patterns of species richness examined. In: J.M. Gili, J.L. Pretus and T.T. Packard (eds.), A marine science odyssey into the 21 st century. Sci. Mar. 65(Suppl. 2): 41-56.

Gray, S., G.C.B. Poore, K.I. Ugland and R.S. Wilson. - 1997. Coastal and deep-sea benthic diversities compared. Mar. Ecol. Prog. Ser. 159: 97-103.

Grimm, V. and C. Wissel. - 1997. Babel, or the ecological stability discussions: an inventory and analysis of terminology and a guide for avoiding confusion. Oecologia 109: 323-334.

Gutt, J. - 2000. Some "driving forces" structuring communities of the sublittoral Antarctic macrobenthos. Antarc. Sci. 12: 297-313.

Gutt, J., D. Gerdes and M. Klages. - 1992. Seasonality and spatial variability in the reproduction of two Antarctic holothurians (Echinodermata). Polar Biol. 11: 533-544.

Gutt, J., A. Starmans and G. Dieckmann. - 1996. Impact of iceberg scouring on polar benthic habitats. Mar. Ecol. Prog. Ser. 137: 311-316.

Gutt, J., V. Storch and W.E. Arntz. - 1998. Benthosforschung im Südpolarmeer: Störung schafft Vielfalt. BIUZ 28: 362-370.

Gutt, J., B.I. Sirenko, W.E. Arntz, I.S. Smirnov and C. De Broyer. - 2000. Biodiversity of the Weddell Sea: macrozoobenthic species (demersal fish included) sampled during the expedition ANT XIII/3 (EASIZ I) with RV "Polarstern". Ber. Polarforsch. 372: $1-103$.

Hain, S. - 1990. Die beschalten benthischen Mollusken (Gastropoda und Bivalvia) des Weddellmeeres, Antarktis. Ber. Polarforsch. 70: 1-180. 
Hain, S. and P. Arnaud. - 1992. Notes on the reproduction of high Antarctic molluscs from the Weddell Sea. Polar Biol. 12: 303-312.

Hayward, P.J. and J.S. Ryland (eds.). - 1995. Handbook of the Marine Fauna of North-West Europe. Oxford University Press, Oxford.

Hedgpeth, J.W. - 1977: The Antarctic marine ecosystem. In: Llano, G.A. (ed.), The Antarctic Marine Ecosystem, pp. 3-10. Gulf Publ. Co., Houston.

Hoegh-Guldberg, O. and J.S. Pearse. - 1995. Temperature, food availability, and the development of marine invertebrate larvae. Am. Zool. 35: 415-425.

Huston, M. - 1979. A general hypothesis of species diversity. Am. Nat. 113: 81-101.

Jazdzewski, K., J.M. Weslawski and C. De Broyer. - 1995. A comparison of the amphipod faunal diversity in two polar fjords: Admiralty Bay, King George Island (Antarctic) and Hornsund, Spitsbergen (Arctic). Pol. Arch. Hydrobiol. 42: 367-384.

Klages, M. - 1993. Biology of the Antarctic gammaridean amphipod Eusirus perdentatus Chevreux, 1912 (Crustacea: Amphipoda): distribution, reproduction and population dynamics. Antarctic Sci. 5: 349-359.

Klages, M. and J. Gutt. - 1990. Comparative studies on the feeding behaviour of high Antarctic amphipods (Crustacea) in the laboratory. Polar Biol. 11: 79-83.

Lancelloti, D. and J.A. Vásquez. - 1999: Biogeographical patterns of benthic invertebrates in the southeastern Pacific littoral. Journal of Biogeography 26: 1001-1006

Lipps, J.H. and C.S. Hickman. - 1982. Origin, age and evolution of Antarctic and deep-sea faunas. In: Ernst, W.G. and J.G. Morin (eds.), The environment of the deep sea, pp. 324-356. Prentice Hall, N.Y.

Lovrich, G. - 1999. Seasonality of larvae of Brachyura and Anomura (Crustacea, Decapoda) in the Beagle Channel, Argentina. In: W.E. Arntz and C. Ríos (eds.), Magellan-Antarctic: Ecosystems that drifted apart. Sci. Mar. 63(Supl. 1): 347-354.

Margalef, R. - 1974. Ecología. Omega, Barcelona.

Margalef, R. - 1991. Teoría de los Sistemas Ecológicos. Publ. De la Univ. de Barcelona, Barcelona.

Margalef, R. - 1997. Our Biosphere. Excellence in Ecology, 10. Ecology Institute, Oldendorff/Luhe.

Menge, B.A. and J.P. Sutherland. - 1976. Species diversity gradients: synthesis of the roles of predation, competition, and temporal heterogeneity. Am. Nat. 100: 351-369

Mileikowsky, S.A. - 1968. Distribution of pelagic larvae of bottom invertebrates of the Norwegian and Barents Sea. Mar. Biol. 1: 161-167.

Mileikowsky, S.A. - 1971. Types of larval development in marine bottom invertebrates, their distribution and ecological significance: a re-evaluation. Mar. Biol. 10: 193-213.

Niermann, U. - 1990. Das Makrobenthos der südöstlichen Nordsee: Fluktuationen in den Jahren 1984-1988. Diss. Univ. Hamburg: $226 \mathrm{pp}$.

Ockelmann, K.W. - 1962. Developmental types in marine bivalves and their distribution along the Atlantic coast of Europe. Proc. First Europ. Malac. Congr.: 25-35.

Olson, R.R. and M.H. Olson. - 1989. Food limitation of planktotrophic marine invertebrate larvae: does it control recruitment success? Ann. Rev. Ecol. Syst. 20: 225-247.

Orejas, C. - 2001. Role of benthic cnidarians in energy transfer processes in the Southern Ocean marine ecosystems (Antarctica). Ber. Polarforsch., 395: 1-186.

Orejas, C., J.-M. Gili and W.E. Arntz. - (submitted a). The role of the fine fraction of seston in the diet of two Antarctic octocorals (Primnoisis antarcticus and Primnoella $\mathrm{sp}$.): ecological implications.

Orejas, C., J.-M. Gili, P. López-González and W.E. Arntz. - (submitted b). Reproductive patterns of four Antarctic octocorals in the Weddell Sea: comparisons across different species, morphologies and latitudes.

Orejas, C., P. López-González, J.-M. Gili, N. Teixidó, J. Gutt and W.E. Arntz. - (submitted c). Distribution and reproductive ecology of the Antarctic octocoral Ainigmaptilon antarcticus in the Weddell Sea.

Orejas, C., J.-M. Gili, P.J. López-González and W.E. Arntz. - (in press). Feeding strategies and diet composition of four Antarctic cnidarian species. Polar Biol.

Pearse, J.S. - 1994. Cold-water echinoderms break Thorson's rule. In: C.M. Young and K.J. Eckelbarger (eds.), Reproduction, Larval Biology, and Recruitment of the Deep-Sea Benthos, pp.
26-39. Columbia University Press, New York.

Pearse, J.S., J.B. McClintock and I. Bosch. - 1991. Reproduction of Antarctic marine invertebrates: tempos, modes and timing. Am. Zool. 31: 65-80.

Pechenik, J.A. - 1999. On the advantages and disadvantages of larval stages in benthic marine invertebrate life cycles. Mar. Ecol. Prog. Ser. 177: 269-297.

Peck, L.S., S. Brockington, S. Vanhove and M. Beghyn. - 1999. Community recovery following catastrophic iceberg impacts in a soft-sediment shallow-water site at Signy Island, Antarctic. Mar. Ecol. Prog. Ser. 186: 1-8.

Picken, G.B. - 1980. The distribution, growth and reproduction of the Antarctic limpet Nacella (Patinigera) concinna (Strebel 1908). J. exp. mar. Biol. Ecol. 42: 71-85.

Piepenburg, D. - 2000. Arctic brittle stars (Echinodermata: Ophiuroidea). Oceanogr. mar. Biol. ann. Rev. 38: 189-256.

Piepenburg, D., M. Schmid and D. Gerdes. - (in press). The benthos of King George Island (South Shetland Islands, Antarctica): further evidence for a lack of a latitudinal biomass cline between Magellan, South America and high Antarctic Weddell Sea. Polar Biol.

Popper, K. - 1972. Objective Knowledge: An Evolutionary Approach. Clarendon Press, Oxford.

Poulin, E. and J.-P. Féral. - 1994. The fiction and the facts of Antarctic brood protecting: population genetics and evolution of schizasterid echinoids. In: B. David, A. Guille, J.-P. Féral and M. Roux (eds.), Echinoderms through Time, pp. 837-844. Balkema, Rotterdam.

Poulin, E. and J.-P. Féral. - 1996. Why are there so many species of brooding Antarctic echinoids? Evolution 50: 820-830.

Poulin, E., S.v. Boletzky and J.-P. Féral. - 2001. Combined ecological factors permit classification of developmental patterns in marine invertebrates: a discussion note. J.exp. mar. Biol. Ecol. 257: 109-115.

Richer de Forges, B., J.A. Koslow and G.C.B. Poore. - 2000. Diversity and endemism of the benthic seamount fauna in the southwest Pacific. Nature 405: 944-947.

Riedl, R. - 1966. Biologie der Meereshöhlen. Paul Parey, Hamburg.

Riedl, R. - 1980. Marine Ecology - A Century of Changes. P.S.Z.N. I: Mar. Ecol., 1: 3-46.

Riemann, F. - 1989. Gelatinous phytoplankton detritus aggregates on the Atlantic deep-sea bed. Structure and mode of formation. Mar. Biol. 100: 533-539.

Sakshaug, E. - 1994. Discussant's report: Primary production in the Antarctic pelagial - a view from the North. In: S.Z. El-Sayed (ed.), Southern Ocean Ecology: the BIOMASS Perspective. Cambridge Univ. Press, Cambridge: 125

Sanders, H.L. - 1968. Benthic marine diversity and the stability time hypothesis. Brookhaven Symp. Biol. 22: 71-81

Sanders, H.L. - 1969. Marine benthic diversity: a comparative study. Am. Nat. 102: 243-282

Sanders, H.L. - 1979. Evolutionary ecology and life-history patterns in the deep sea. Sarsia 64: 1-7

Schlüter, M. - 1998. Die räumliche und zeitliche Verteilung des Meroplanktons (Larven des Evertebraten-Benthos) in der zentralen Barentssee. Dipl. Thesis Univ. Bremen: 79 pp.

Sirenko, B., I. Smirnov and W.E. Arntz. - 1997. Taxonomic biodiversity of bottom invertebrates in the eastern Weddell Sea. In: Arntz, W.E. and J. Gutt (eds.), The Expedition Antarktis XIII/3 (EASIZ I) of Polarstern to the eastern Weddell Sea in 1996. Ber. Polarforsch. 249: 25-31

Slattery, M., J.B. McClintock and S.S. Bowser. - 1997. Deposit feeding: a novel mode of nutrition in the Antarctic colonial soft coral Gersemia antarctica. Mar. Ecol. Prog. Ser. 149: 299-304.

Smidt, E.L.B. - 1979. Annual cycles of primary production and of zooplankton at Southwest Greenland. Greenl. Bioscience 1: 1-53.

Stanwell-Smith, D. and L.S. Peck. - 1998. Temperature and embryonic development in relation to spawning and field occurrence of larvae of three Antarctic echinoderms. Biol. Bull. 194: 44-52.

Stanwell-Smith, D., L.S. Peck, A. Clarke, A.W.A. Murray and C.D. Todd. - 1999. The distribution, abundance and seasonality of pelagic marine invertebrate larvae in the maritime Antarctic. Phil. Trans. R. Soc. Lond. B 354: 471-484

Stehli, F.G., A. McAlester and C.E. Helsley. - 1967. Taxonomic diversity of recent bivalves and some implications for geology. Bull. Geol. Soc. America 78: 455-466.

Tarazona, J. and S. Valle. - 1999. La diversidad biológica en el mar peruano. In: G. Halffter (ed.) Diversidad biológica en 
Iberoamérica, pp. 99-109. Programa CITED vol. III, Veracruz. Tarazona, J., H. Salzwedel and W.E. Arntz. - 1988. Positive effects of El Niño on macrozoobenthos inhabiting hypoxic areas of the Peruvian upwelling system. Oecologia 76: 184-190.

Thorson, G. - 1936. The larval development, growth and metabolism of Arctic marine bottom invertebrates compared with those of other seas. Medd. om Grönland 100: 1-155.

Thorson, G. - 1946. Reproduction and larval development of Danish marine bottom invertebrates, with special reference to the planktonic larvae in the sound (Øresund). Meddr. Kommn. Danm. Fiskeri-og Havunders. Ser. Plankton 4: 1-523.

Thorson, G. - 1950. Reproductive and larval ecology of marine bottom invertebrates. Biol. Rev. 25: 1-45.

Thorson, G. - 1957. Bottom communities (sublittoral or shallow shelf). In: J.W. Hedgpeth (ed.), Treatise on Marine Ecology and Palaeoecology, 461-534.. Geol. Soc. America.

Todd, C.D. - 1998. Larval supply and recruitment of benthic invertebrates: Do larvae always disperse as much as we believe?
Hydrobiologia 375/376: 1-21.

Volterra, V. - 1928. Animal Ecology. McGraw-Hill, New York.

Warwick, R.M. - 1995. Biodiversity and production on the sea floor. In: G. Hempel (ed.), The Ocean and the Poles, pp. $217-$ 227. Grand Challenges for European Cooperation. Gustav Fischer Verlag, Jena.

White, M.G. - 1984: Marine benthos. In: R.M. Laws (ed.), Antarctic Ecology vol. 2: 421-461. Academic Press, London.

Wieters, E. - 2001. Marine macroecology. Trends Ecol. Evol. 16: 67-69.

Wilson, E.O. - 1988. Biodiversity. Nat. Acad. Press, Washington D.C.

Wottom, R.S. - 1994. The biology of particle in aquatic systems. Lewis Publishers, Boca Raton.

Zettler, M.L., R. Bönsch and F. Gosselck. - 2000. Verbreitung des Makrozoobenthos in der Mecklenburger Bucht (südliche Ostsee) - rezent und im historischen Vergleich. Meereswiss. Berichte IOW 42: 144 pp. 